\title{
Studies on foliicolous fungi-XXXI: the genus Schiffnerula and Sarcinella
}

V.B. Hosagoudar and M.C. Riju

Abstract: This paper gives an account of three species sarciniform, cruciately septate, 4-8 celled, of the genus Schiffnerula and a species of Sarcinalla. Of these, Schiffnerula terminaliae is the new species, Schiffnerula brideliae and $S$. ricinii are reported for the first time from India and sarcinalla allophyli is re-located from the present high altitudinal place.

Keywords. Sarcinella, Schiffnerula, new species, Kerala.

Taxonomy

Sarcinella allophyli Hosag., J. Mycopathol. Res. 44: 20, 2006.

Materials examined: On leaves of Allophyllus sp. (Sapindaceae), $16^{\text {th }}$ mile, Padinharathara, Wayanad, Kerala, India, November 9, 2007, M. C. Riju HCIO 48179, TBGT 2915.

Schiffnerula allophyli Hansf. is known on Allophyllus sp. from Uganda (Hansford, 1946) and Sarcinella allophyli Hosag. is known on Allophyllus cobbe from Coorg, Karnataka (Hosagoudar et al., 2006). Since the present collection also persisted in its anamorph state, it has been assigned to Sarcinella allophyli. Schiffnerula brideliae Hansford, Proc. Linn. Soc. London 1940-41, 1: 4-52

(Fig. 1)

Colonies amphigenous, thin, up to $2 \mathrm{~mm}$ in diameter, confluent. Hyphae substraight to flexuous, branching opposite, alternate to unilateral at acute to wide angles, loosely reticulate, cells $13-38$ x 4-7 $\mu \mathrm{m}$. Appressoria alternate, unilaterate, globose, mammiform, entire, 6-13 x 6-11 $\mu \mathrm{m}$. Conidia of Questieriella scattered in the colonies, curved, 3-septate, slightly constricted at the septa, taper towards both ends, $28-30 \times 8-11$ $\mu \mathrm{m}$. Conidiophores of Sarcinella produced lateral to the hyphae, single, straight to flexuous, macronematous, mononematous, 0-3 septate, 4-7 x 6-96 $\mu \mathrm{m}$; conidiogenous cells terminal, monoblastic, integrated, cylindrical; conidia blastic, terminal, mostly sessile, solitary, dry, ovate to globose,
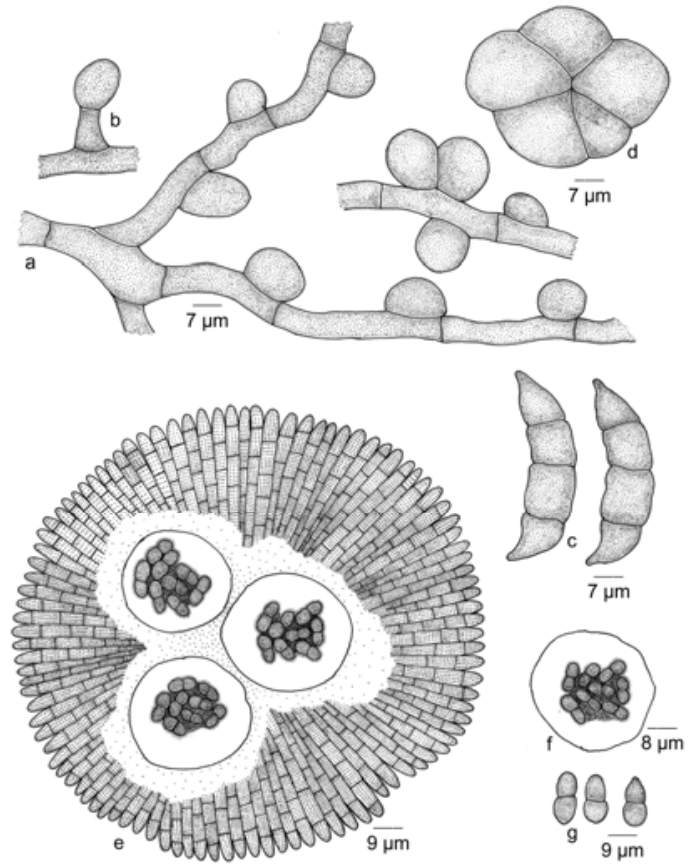

Fig. 1. Schiffnerula briedeliae Hansf.

a-Appressoriate mycelium, b- Conidiophore of Sarcinella, c-Conidia of Questieriella, d- Conidium of Sarcinella,

e- Thyriothecium with exposed asci, f-Ascus, g-Ascospores

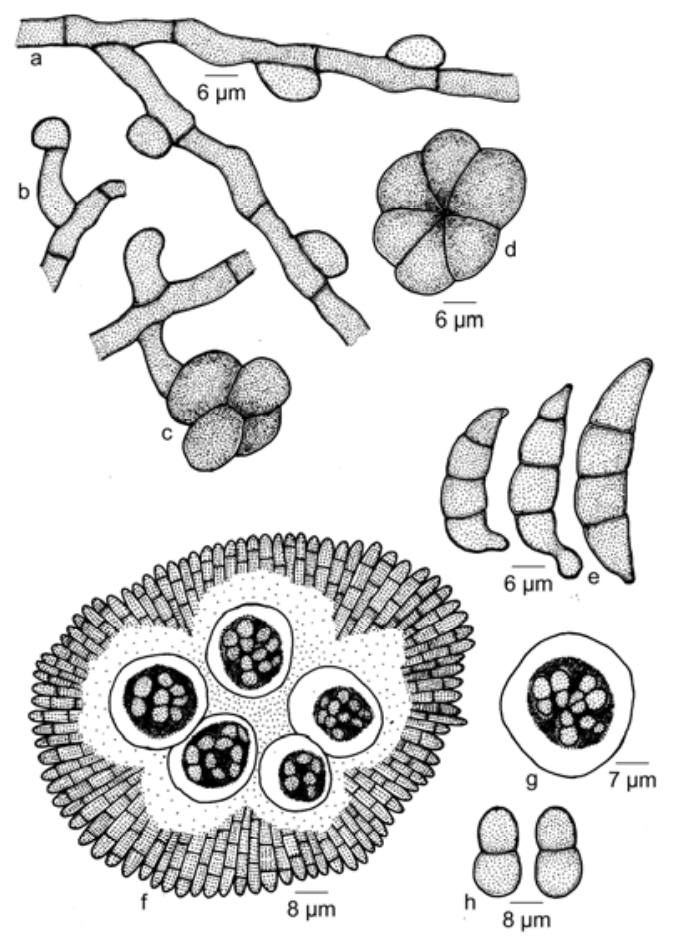

Fig. 2. Schiffnerula ricini Hansf

a-Appressoriate mycelium, b-Conidiophore of Sarcinella, c- Developing conidium of Sarcinella, d-Conidium of Sarcinella, e- Conidia of Questieriella, f- Thyriothecium with exposed asci, g-Ascus, h-Ascospores constricted at the septa, 26$40 \mu \mathrm{m}$ in diameter, wall smooth. Thyriothecia scattered, globose, ovate, peridial cells initially radiating, later central portion dissolved by exposing asci, up to $121 \mu \mathrm{m}$ in diam.; asci 3-4 per thyriothecia, globose, octosporous, bitunicate, 27$32 \mu \mathrm{m}$ in diameter; ascospores oblong, conglobate, uniseptate, constricted at the septum, 8-13 $x$ 5-7 $\mu \mathrm{m}$, remain hyaline for some time but turn brown at maturity, wall smooth.

Material examined: On leaves of Bridelia sp. (Euphorbiaceae), $16^{\text {th }}$ mile, Padinharathara, Wayanad, Kerala, India, November 10, 2007, M. C. Riju $\mathrm{HClO}$ 48169, 48172, TBGT 2905, 2908.

This fungus was known on Bridelia macrantha from Uganda (Hansford, 1941) and is reported new for the first time from India (Bilgrami et al. 1991).

Schiffnerula ricini Hansf., Proc. Linn. Soc. London 160: 117, 1947-48; Hosag., H. Biju \& Appaiah, J. Mycopathol. Res. 4: 23, 2006. (Fig.2)

Colonies amphigenous, up to $3 \mathrm{~mm}$ in diameter, epiphyllous colonies subdense, confluent, hypophyllous colonies crustose, some times confluent. Hyphae substraight to flexuous, branching opposite, irregular at acute to wide angles, loosely reticulate, cells $8-33 \times 2-5 \mu \mathrm{m}$. Appressoria alternate, unilateral, globose, mammiform, entire, $6-9$ x 6-10 $\mu \mathrm{m}$. Conidia of Questieriella were scattered, mostly not attached, curved, 3septate, slightly constricted at the septa, taper towards both ends, 26-31 $x$ 8-11 $\mu \mathrm{m}$. Sarcinella conidiophores produced lateral to the hyphae, single, straight to 
flexuous, macronematous, mononematous, 0-2 septate, $9-12 \times 2-5 \mu \mathrm{m}$, conidiogenous cells terminal, monoblastic, integrated, cylindrical; conidia present mostly on the lower surface of the leaves, blastic, terminal, solitary, dry, ovate to globose, sarciniform, cruciately septate, 4-8 celled, constricted at the septa, 19-31 $\mu \mathrm{m}$ in diameter, brown, and tern to dark at maturity, wall smooth. Thyriothecia mostly on the upper surface of the leaves, scattered, globose, orbicular to ovate, peridial cells initially radiating, later central portion dissolved by exposing asci, up to $110 \mu \mathrm{m}$ in diam., marginal cells mostly persist and radiate; asci 4-8 per thyriothecia, globose, octosporous, bitunicate, 22-29 $\mu \mathrm{m}$ in diameter; ascospores oblong, conglobate, uniseptate, constricted at the septum, 19-22 x 8-11 $\mu \mathrm{m}$, remain hyaline for some time but turn brown at maturity.

Materials examined: On leaves of Ricinus communis L. (Euphorbiaceae), Puthusserikkadavu, Padinharathara, Wayanad, Kerala, India, Nov. 10, 2007, M. C. Riju HCIO 48180, TBGT 2916

This species was reported on the same host from Uganda, (Hansford, 1948). Later, Sarcinella state of this fungus was reported from Coorg, Karnataka (Hosagoudar et al., 2006). However, the present collection revealed both the anamorphs and teleomorph. This reveals the affinity of the fungal flora of Uganda, Coorg and Wayanad and appears to occur only in highly elevated places.

\section{Schiffnerula terminaliae sp. nov. (Fig. 3)}

Anamorph: Questieriella terminaliae Hosag. \& Agarwal, Indian Phytopath. 55: 501, 2002.

Coloniae amphigenae, densae vel subdensae, confluentes, ad 6 $\mathrm{mm}$ diam. Hyphae rectae vel subrectae, alternatim, unilateralis vel oppositis, ad laxe vel arte ramosae, laxe vel densae reticulatae, cellulae 13-51 x 2-5 $\mu \mathrm{m}$. Appressoria alternata, vel unilateralis, globosa, mammiformes, integra, $\quad 4-11 \quad x \quad 4-9 \quad \mu \mathrm{m}$. Conidiophora Questieriella hyphis lateralis producentes, solitaria, recta vel flexuosa, macronemata, mononemata, 0-3 septata, 17-22 x 6-9 $\mu \mathrm{m}$; cellulae conidiogenae terminalis, monoblasticae, integratae, cylindraceae; conidia pauca, plerumque in coloniis dispersa, curvula, 3-septata, leniter constrictae ad septatae, attenuatae ad ambi apicem, 24-46 x 6-11 $\mu \mathrm{m}$. Thyriothecia dispersa, orbicularis, ovata, cellulae peridiales radiatae ad initio, portionio centralis soltum ad maturitata, ad $176 \mu \mathrm{m}$ diam., cellulae ad margine radiatae; asci 3-10 numero, oblongi

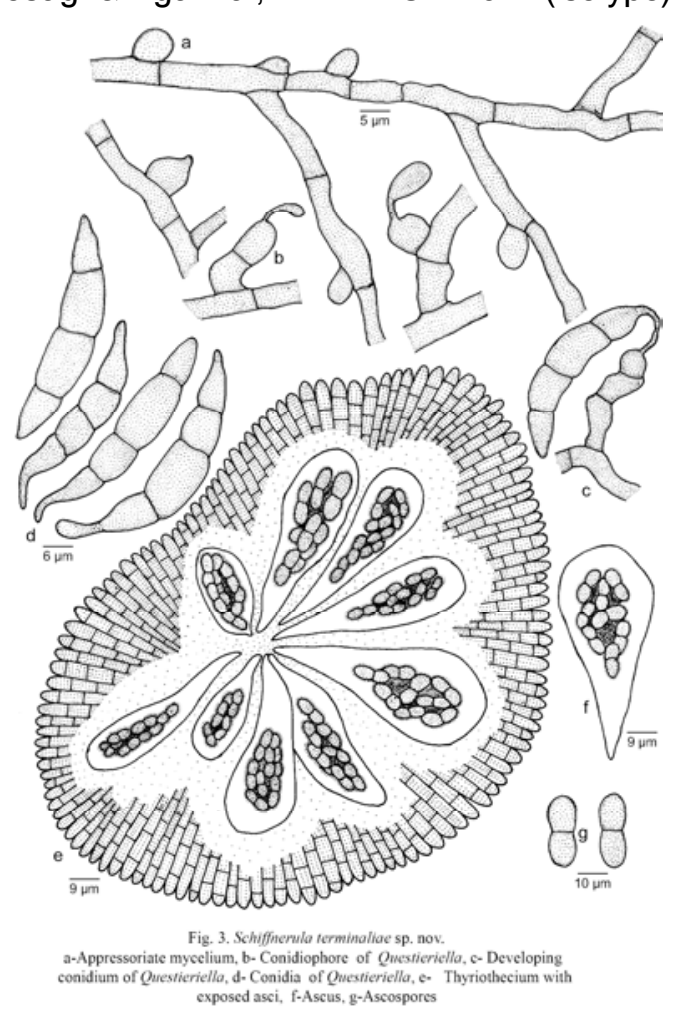

Res. 44, 1-25. vel clavati, octospori, bitunicati, 39-46 x 15-31 $\mu \mathrm{m}$; ascosporae oblongae, conglobatae, uniseptatae, constrictae ad septatae, $17-24 \times 6-9 \mu \mathrm{m}$, sporae ad initio hyalinae, brunneae ad maturitatae, parietus glabrus.

Colonies amphigenous, subdense to dense, confluent, up to $6 \mathrm{~mm}$ in diameter. Hyphae straight to sub straight, branching alternate, unilateral to opposite, branching at acute to wide angles, loosely to closely reticulate, cells $13-51 \times 2-5 \mu \mathrm{m}$. Appressoria alternate to unilateral, globose, mammiform, entire, 4-11 x 4-9 $\mu \mathrm{m}$. Questieriella conidiophores produced lateral to the hyphae, single, straight to flexuous macronematous, mononematous, $0-3$ septate, 18-24 x 6-9 $\mu \mathrm{m}$; conidiogenous cells terminal, monoblastic, integrated, cylindrical; conidia few, mostly scattered in the colonies, few attached to the conidiophores, curved, 3-septate, slightly constricted at the septa, taper towards both ends, 24-46 x 6-11 $\mu \mathrm{m}$. Thyriothecia scattered, orbicular, ovate, peridial cells initially radiating, later central portion dissolved by exposing the asci, up to 176 $\mu \mathrm{m}$ in diam., marginal cells radiating; asci 3-10 per thyriothecia, oblong to clavate, octosporous, bitunicate, $39-46 \times 15-31 \mu \mathrm{m}$; ascospores oblong, conglobate, uniseptate, constricted at the septum, 17-24 x 6-9 $\mu \mathrm{m}$, remain hyaline for some time but turn brown at maturity, wall smooth.

Materials examined: On leaves of Terminalia catapa L. (Combretaceae), Palode, Thiruvananthapuram, Kerala, India, Sept. 15, 2007, M. C. Riju HClO 48181 (Type), TBGT 2917 (isotype).

Hosagoudar et al. (2002) have proposed Questieriella terminaliae Hosag. \& Agarwal from Kerala and the present collection revealed its ascigerous state.

References

1. Bilgrami KS, Jamaluddin $S$ and Rizwi MA (1991) Fungi of India. List and references. Today \& Tomorrow's printers and Publishers, New Delhi.

2. Hansford CG (1941) Contributions towards the fungus flora of UgandaIII. Some Uganda Ascomycetes. Proc. Linn. Soc. London. 1, 4-52.

3. Hansford CG (1948) Tropical fungi-III. New species and revisions. Ibid. 160, 116-153.

4. Hansford CG (1946) Contributions towards the fungus flora of UgandaVIII. New Records. Ibid.151,138-212.

5. Hosagoudar VB, Biju CK, Abraham TK and Agarwal DK (2002) Studies on foliicolous fungi III. Indian Phytopath. 55, 497-502.

6. Hosagoudar VB, Biju $\mathrm{H}$ and Anu Appaiah KA (2006) Studies on foliicolous fungi - XX. Microfungi of Coorg, Karnataka. J. Mycopathol.
Research article

CIndian Society for Education and Environment (iSee)
"Foliicolous fungi"

http://www.indjst.org
Hosagoudar \& Riju Indian J.Sci.Technol. 